\title{
MALIGNANT GOUT WITH TOPHACEOUS SMALL INTESTINE AND MEGALOBLASTIC ANAEMIA
}

BY

\author{
C. F. HAWKINS, H. A. ELLIS, AND ANNETTE RAWSON \\ From the Rheumatism Research Wing, Queen Elizabeth Hospital, Birmingham
}

Gout, like diabetes, is worst in youth. Often impossible to control by uricosuric drugs, it may cause premature death. Such was the case of a man described by Kersley, Mandel, and Jeffrey (1950). He developed gout at 18 years, became crippled at 21, and died at 24 from bronchopneumonia, associated with a tophus in the atlas vertebra. His brother, who came under our care, also developed gout at 18 years, and pursued a similar course (Fig. 1), though he survived until age 32 , when he died from renal failure. This patient too showed many features of interest.

\section{Case Report}

Attacks of pain in the big toe joint began at 18 years, and usually started during the night. All joints soon became involved and at 20 years there were typical radiological changes in the bones. At 21 years, many large tophi had developed, with numerous discharging areas around severely deformed joints. The serum uric acid was $16 \mathrm{mg}$. per cent. At 24 the patient was crippleda tall, thin, pale man, walking with difficulty. His weight had fallen rapidly from 70 to $50 \mathrm{~kg}$. He was $1 \cdot 8$ metres $(6 \mathrm{ft})$ tall. Typical tophi were present on the ears. All fingers were affected, with tophaceous deposits varying in size up to $3 \mathrm{~cm}$. in diameter, and numerous discharging sinuses. Both elbows were gouty. There was stiffness of the shoulders and effusions into both knee joints. Renal damage was then discovered; the urine contained protein, red cells, and casts, and the creatinine clearance was $19 \mathrm{ml}$. per min., though the serum urea was normal $(24 \mathrm{mg} . / 100 \mathrm{ml}$.). The Congo red test for amyloidosis was negative. The cardiovascular system, including the blood pressure $(120 / 70 \mathrm{~mm}$. $\mathrm{Hg})$, was normal. The pallor was due to a macrocytic anaemia, haemoglobin $9 \cdot 9$ g. per $100 \mathrm{ml}$. (68 per cent.); red blood cells $2,870,000 / \mathrm{mm}^{3}$, colour index $1 \cdot 19$; white blood cells $12,700 / \mathrm{mm}^{3}$, with a normal differential count; platelets $700,000 / \mathrm{mm}^{3}$.

\begin{tabular}{|c|c|c|c|}
\hline \multicolumn{2}{|r|}{ A. Kersley, Mandel, and Jeffrey, 1950} & \multicolumn{2}{|r|}{ B. Present Case, 1965} \\
\hline Age & Progress of Disease & Age & Progress of Disease \\
\hline 18 & Typical attacks of gout in knee & 18 & Typical attacks of gout in big toe \\
\hline 19 & $\begin{array}{l}\text { Pensioned from army with "Rheumatoid } \\
\text { Arthritis" }\end{array}$ & & \\
\hline 20 & Most joints involved & 20 & $\begin{array}{l}\text { Most joints involved } \\
\text { Characteristic x-ray changes } \\
\text { Pensioned from army with "Rheumatoid } \\
\text { Arthritis" }\end{array}$ \\
\hline 21 & $\begin{array}{l}\text { Severe crippling } \\
\text { Discharging tophi } \\
\text { Renal damage }\end{array}$ & 21 & Multiple tophi: many discharging \\
\hline \multirow[t]{2}{*}{24} & $\begin{array}{l}\text { Destruction of atlas vertebra by tophus } \\
\text { Death from bronchopneumonia }\end{array}$ & 24 & Renal damage first noted \\
\hline & & 32 & $\begin{array}{l}\text { A cripple just able to hobble with two sticks } \\
\text { Emaciated and aged in appearance } \\
\text { Died from ileus and uraemia }\end{array}$ \\
\hline
\end{tabular}

Fig. 1.-History of two brothers with gout. The serum uric acid was $16 \mathrm{mg}$. per $100 \mathrm{ml}$. in each case. 
At 30 years, he had contracted pulmonary tuberculosis (left upper lobe) and the sputum contained tubercle bacilli; previous radiographs had been normal. He was treated with para-aminosalicylic acid and isoniazid for 2 years; streptomycin was given for a short time only because of sensitivity.

His health had been normal before the onset of gout. There was no family history of gout. The serum uric acid of his mother was raised $(6 \cdot 8 \mathrm{mg}$. $/ 100 \mathrm{ml}$.), though she was symptomless. There was no consanguinity.

At 32, the year of his death, he presented a pathetic appearance: thin, emaciated, and aged. He was crippled, being just able to hobble with two sticks, and weighed $54 \mathrm{~kg}$. (8 st. $10 \mathrm{lb}$.). Both hands were extremely deformed, the fingers being like sausages due to distension with tophaceous deposits (Fig. 2). There was bilateral tophaceous olecranon bursitis. The feet were similar to the hands and he could wear only large bedroom slippers. Radiographs showed severe gouty destruction-arthritis mutilans- - of all the interphalangeal joints of the fingers and toes (Figs 3 and 4), as well as of the wrists, intertarsal joints, and ankles; and, to a lesser degree, of the shoulders, elbows, knees, and hips. There was extensive calcification of tophi. Typical radiological changes of gout were also observed in the sacro-iliac joints. Serum uric acid was $15.7 \mathrm{mg}$. and serum cholesterol $135 \mathrm{mg} . / 100 \mathrm{ml}$. Blood pressure $125 / 80 \mathrm{~mm}$. $\mathrm{Hg}$. He had diarrhoea and was passing eight stools daily.

Many drugs had been tried, but he was sure that colchicine was his mainstay in life, and had taken this

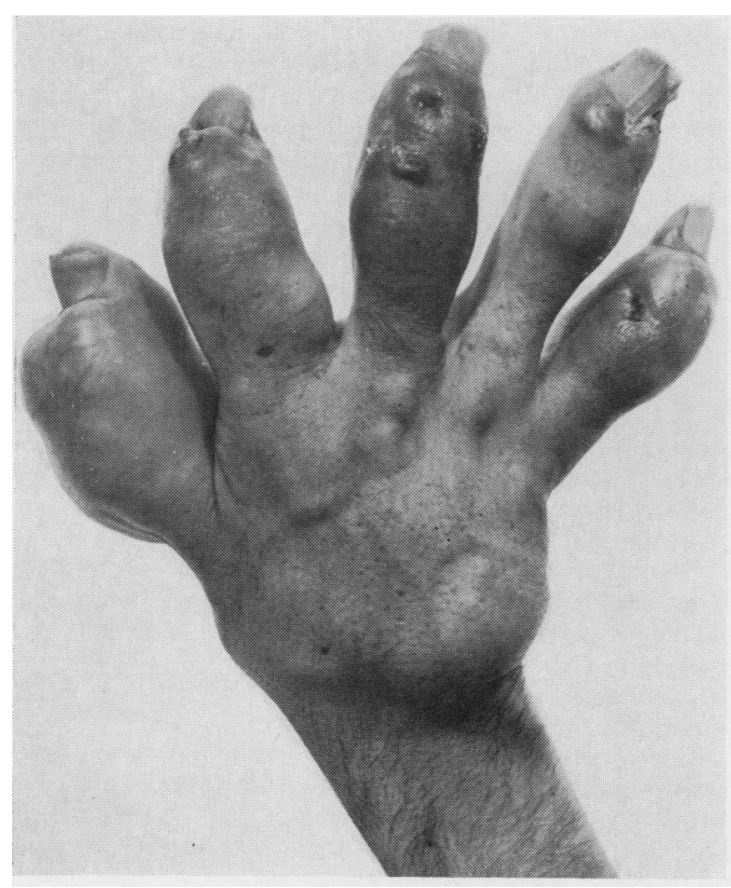

Fig. 2.--Right hand, showing distortion of fingers from tophaceous

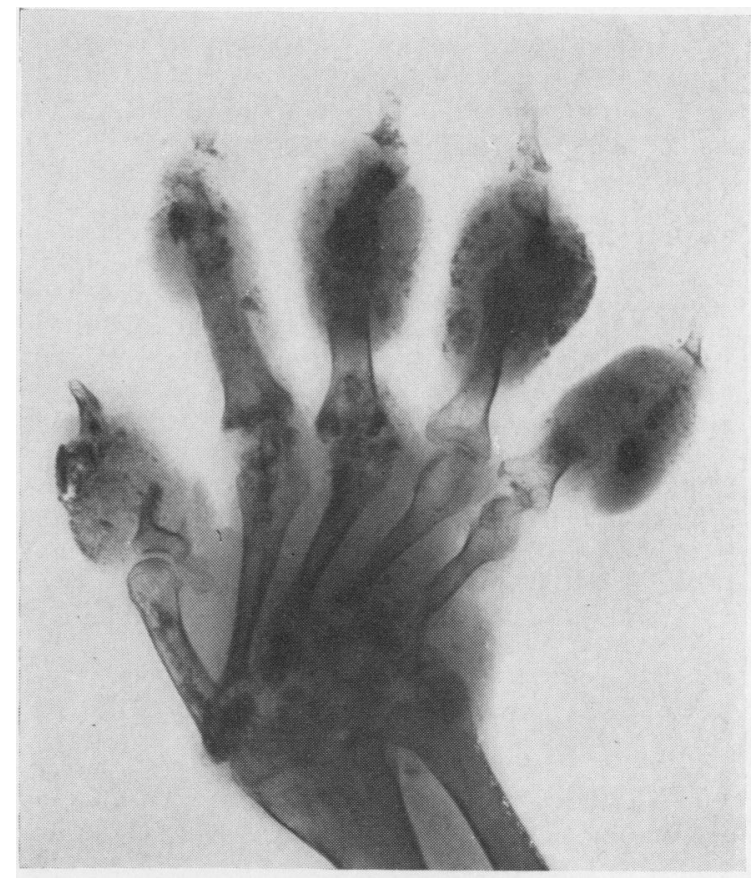

Fig. 3.- Radiograph of right hand.

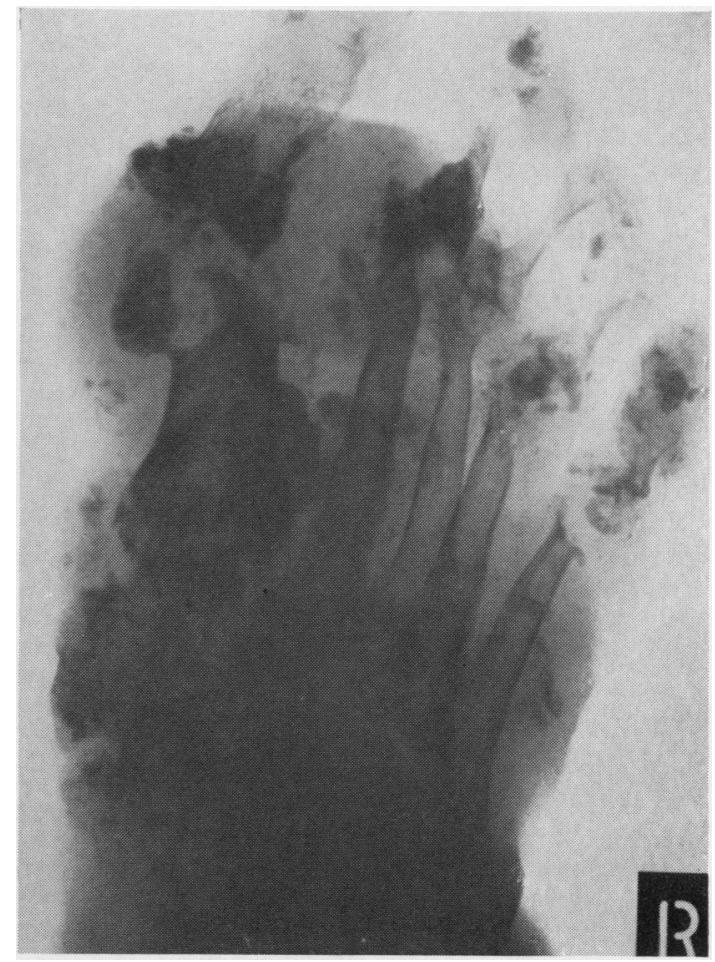

Fig. 4.-Radiograph showing severe gouty destruction (arthritis mutilans) of the joints of the foot. 
regularly for 12 years, usually $0.5 \mathrm{mg}$. three times daily (larger doses caused diarrhoea), preferring it to corticotrophin, Anturan (sulphinpyrazone), or aspirin. When his colchicine was stopped, a relapse occurred at once and the joints of the hands and elsewhere became swollen and painful. He then fell ill with fever and, sometimes, delirium and hallucinations, so that admission to a mental hospital had to be considered. Deprivation of colchicine was a particular hazard of admission to hospital, for he would be kept under observation without colchicine. His brother, who had taken colchicine for 3 years, experienced similar withdrawal symptoms. Large doses of sodium salicylate had been prescribed for long periods to reduce the serum uric acid, and at other times Anturan-which caused dyspepsia, but neither clinical nor chemical control was possible. Probenecid, $250 \mathrm{mg}$. four times daily, caused a temporary fall in the serum uric acid level from 16 to $8.6 \mathrm{mg}$. per cent. and a rise in the urinary excretion to $6 \mathrm{~g}$. daily for several days. This drug was prescribed for him to take regularly, but it is doubtful whether he did so.

At the time of his last admission to hospital, renal failure was present. Serum urea $121 \mathrm{mg} . / 100 \mathrm{ml}$. Serum sodium $140 \mathrm{mEq}$; serum potassium 4.6 mEq.; and serum chloride $102 \mathrm{mEq} / 100 \mathrm{ml}$. Serum uric acid $19.6 \mathrm{mg} . / 100 \mathrm{ml}$. (Brown's method); total serum proteins $7.6 \mathrm{~g} . / 100 \mathrm{ml}$. Waaler-Rose test negative. Haemoglobin 11.4 g. $/ 100 \mathrm{ml}$. (78 per cent.), red blood cells $3,670,000 / \mathrm{mm}^{3}$, packed cell volume 38 per cent., mean corpuscular volume 102 c. $\mu$., mean corpuscular haemoglobin concentration 30 per cent.; white cells $9,100 /$ $\mathrm{mm} .{ }^{3}$; differential count normal.

Megaloblasts were seen in the bone marrow though the majority of cells were normoblasts and macronormoblasts; the myeloid cells appeared normal apart from occasional multi-lobed polymorphs and giant metamyelocytes (reported by Dr. M. A. R. King).

The serum vitamin $B_{12}$ (Euglena assay) level was 280 $\mu \mu \mathrm{g} . / \mathrm{ml}$., and a folic acid clearance test (Chanarin, Mollin, and Anderson, 1958) showed disappearance of all folic acid activity from the serum in $\mathbf{1 5}$ minutes after intravenous injection of $15 \mu \mathrm{g} . / \mathrm{kg}$. folic acid. Serum iron was $58 \mu \mathrm{g} . / 100 \mathrm{ml}$.; total iron-binding capacity 380 $\mu \mathrm{g} . / 100 \mathrm{ml}$.

The gastric juice contained hydrochloric acid. A barium progress meal (using "Raybar") showed a normal small intestine without dilatation or other sign of idiopathic steatorrhoea. The stools were loose, with flecks of mucus. The excretion of faecal fat over 7 days was on the upper limit of normal, being 6 to $7 \mathrm{~g}$. daily.

A specimen of jejunal mucosa obtained by the Crosby capsule (Fig. 5, opposite) was abnormal though without showing the typical flat appearance of idiopathic steatorrhoea. The villi were somewhat distorted and irregular in shape. The surface epithelium in some areas showed irregularity in the nuclear pattern, due in part to the presence of infiltrating lymphocytes and occasional plasma cells. The appearance of the villi varied somewhat in the different sections and in different parts of the same section. In some areas a few comparatively normal villi were present. There was an increase in the number of plasma cells and lymphocytes in the lamina propria. Urate deposits were not present. Mitotic figures in the gland crypts appeared to be present in normal numbers.

The anaemia showed no response to vitamin $B_{12}$ but oral folic acid was effective and the bone marrow became normoblastic. Although so seriously ill, the time of death was unexpected. The patient developed colicky abdominal pain, distension, and vomiting after a jejunal biopsy, shortly followed by a barium meal. Plain radiographs showed distended loops of small bowel without evidence of perforation, and there was no sign of obstruction from barium. As no improvement followed gastric suction with intravenous fluid and electrolyte replacement over 5 days, a laparotomy was performed (by $\mathrm{Mr}$. Arnold Gourevitch). Ileus alone was found. The serous surface of the bowel looked inflamed. The mesentery was thickened and many lymph nodes were enlarged. After the operation, the paralytic ileus persisted and large volumes were aspirated. In spite of careful fluid and electrolyte replacement (including potassium), the patient died on the fifteenth day.

Necropsy.-The stomach, duodenum, and proximal small intestine were distended with fluid though without evidence of obstruction or peritonitis. The mesentery was slightly thickened and firm near the border of the material were visible (Fig. 6, opposite). The mucosa of the small intestine also contained occasional deposits of similar material. A superficial ulcer was present at the site of jejunal biopsy, as might be expected. The liver appeared normal. The spleen $(210 \mathrm{~g}$.) was congested and slightly enlarged. The gall bladder, bile ducts, and pancreas were normal. Both kidneys were small and the capsules stripped with difficulty, revealing a coarse granular surface, with a "cobblestone" pattern. The corticomedullary junctions were ill-defined on the cut surfaces and the cortices were thin. There were multiple small deposits of firm white material throughout the parenchyma, particularly in the medulla of each kidney. The renal blood vessels, pelves, ureters, bladder, prostate, and testes were all normal. No abnormality was found in the meninges, cerebral vessels, or brain.

There were old fibrous adhesions partly obliterating each pleural cavity, and there was bronchopneumonic consolidation of the entire right lung and left lower lobe. A cavity $(1.0 \times 1.2 \mathrm{~cm}$.) was present in the left upper lobe, adjacent to the main fissure, and contained partly calcified caseous material. To one side of this was a smaller rounded calcified nodule measuring $0.5 \mathrm{~cm}$. in diameter.

The heart (330 g.) showed moderate left ventricular hypertrophy, the myocardium measuring $1.8 \mathrm{~cm}$. in width. Otherwise the heart valves and chambers were normal. There were no deposits of urates in the heart. The coronary arteries and aorta were almost free from atheroma.

There was hyperplastic red marrow throughout the sternum and bodies of the lumbar vertebrae and in the upper two-thirds of the femora.

The articular cartilages of the sternoclavicular joints were partly eroded and flecked with white deposits of urates. The knee joint cavities were distended with 


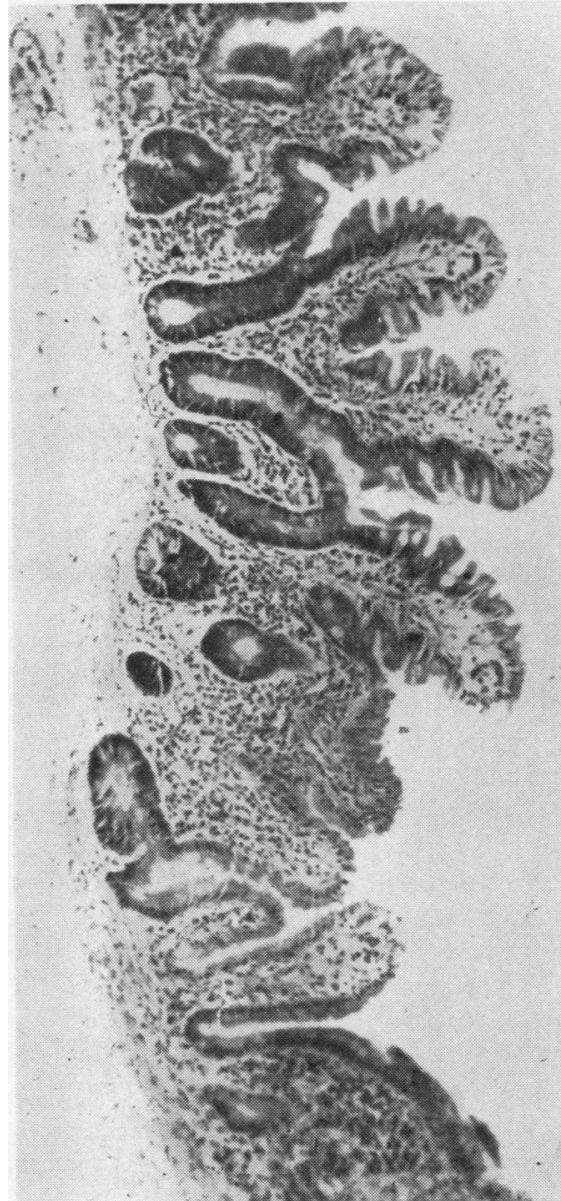

(a)

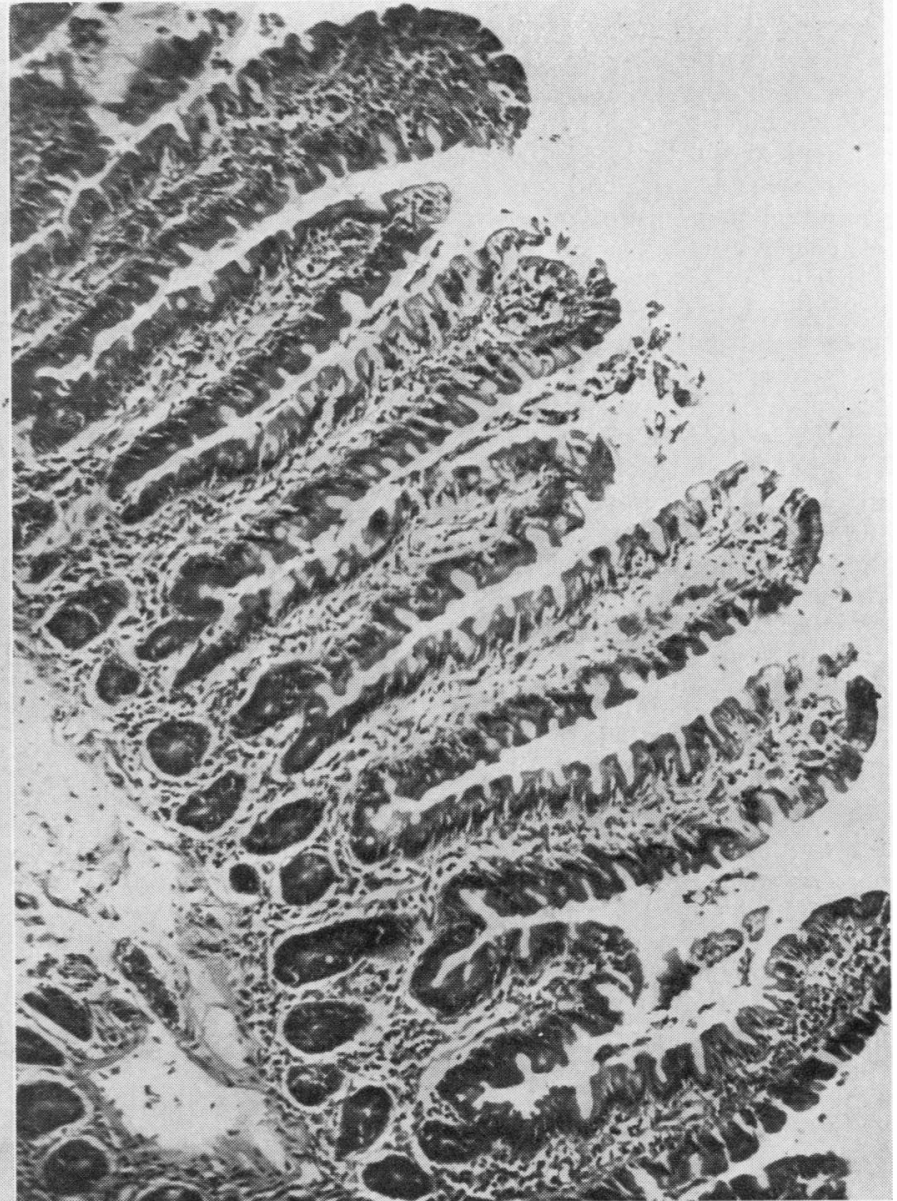

(b)

Fig. 5(a) - Specimen of jejunal mucosa obtained by biopsy (Crosby capsule). The villi are blunted, distorted, and irregular in shape. Fig. $5(b)$. - Specimen of jejunal mucosa, showing appearance of villi from a normal person.

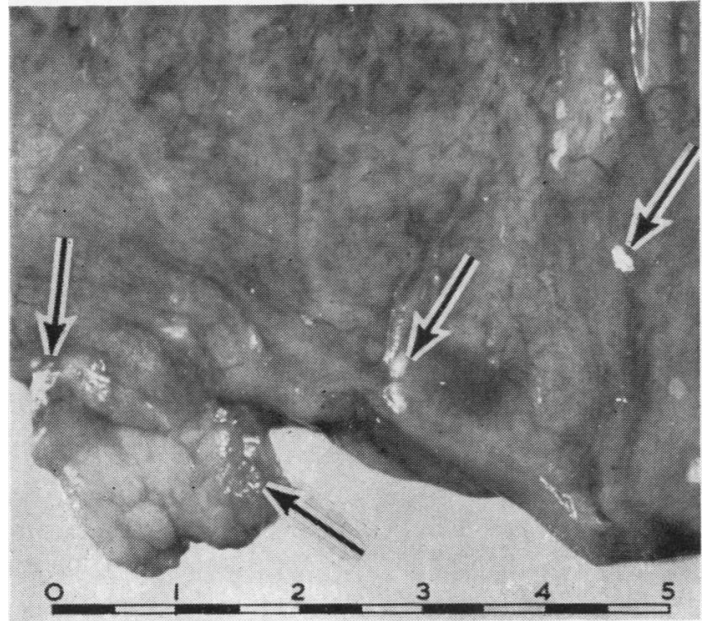

white, thin putty-like material and there were hard chalk-like deposits on the cartilaginous surfaces, which were also partly eroded. Microscopic examination of smears of the material from the joints revealed crystals of urate. The crystalline nature of this material was particularly well seen under the polarizing microscope.

Histological Appearances.-Material was fixed in formal saline and in alcohol to preserve urates. Sections were stained with haematoxylin and eosin by Van Gieson's stain and with silver stain for urates. Tissue

Fig. 6.-External surface of small intestine as seen at necropsy, showing numerous tophi (arrowed). Scale in centimetres. 
containing urates was also examined unstained under the polarizing microscope.

The thyroid, parathyroids, adrenal, prostate, heart, and pancreas showed no significant abnormalities. There were congestive changes in the spleen, and in the liver a mild degree of fatty change. The lungs showed extensive non-tuberculous bronchopneumonia. The lesion in the left upper lobe proved to be active chronic fibrocaseous tuberculosis, and tubercle bacilli were present in large numbers.

Post mortem autolysis of the gastrointestinal tract mucosa rendered it unsuitable for detailed histological observations, though certain features could be recognized. The gastric mucosa was not atrophic, and oxyntic and chief cells were discernible. In the small intestine there were multiple foci of urate crystals in the mucosa, submucosa, and serosa; numerous random sections showed a fairly widespread distribution of urate deposits, though many were barely visible to the naked eye. Some of those situated in the serosa and others in the mesentery were associated with fibrosis and a multinucleated foreign-body giant cell reaction. Tubercle bacilli were not identified in these lesions, nor did the mesenteric lymph nodes show evidence of tuberculosis.

The kidneys showed scarring of the cortex and medulla, with multiple foci of urate crystals in the medulla. Some crystals were clearly forming casts within the tubules; elsewhere, the residual portions of the tubular epithelium were barely recognizable and the deposits appeared to be situated within the interstitial substance of the kidney. The urates were present in crystalline and amorphous form and both gave positive staining reactions. In addition, the crystals were birefringent. The deposits of crystals were arranged in a radial manner with a multinuclear foreign-body giant cell reaction at their periphery. There was medial hypertrophy of the small arteries in the kidney with reduplications of their internal elastic lamellae. Many foci of glomeruli were hyalinized and surrounded by lymphocytes. There was no evidence of a pyelonephritis. The appearances in the kidney were characteristic of gouty nephropathy.

The femoral bone marrow was hypercellular. Sections of the knee joint capsule revealed multiple deposits of amorphous masses of urates together with urate crystals. There was a proliferative synovial lesion with formation of a pannus comprising vascular granulation tissue. Degenerative changes were present in the articular cartilage. Deposits of urates were present in the synovium and within the marrow. Sections of the sternoclavicular joints also showed chronic gouty arthritis.

\section{Discussion}

We use the term "malignant" to describe this type of gout because its rapid progress causes early death, as in "malignant" hypertension. The occurrence in youth and the mutilating destruction of joints are remarkable. Tophaceous deposits are widespread and may be calcified (Kersley and others, 1950), the significance of which is not understood (Lichtenstein,
Scott, and Levin, 1956). Uricosuric drugs have little effect.

\section{Gout in Youth}

Primary gout is rare in childhood. The youngest case was described by Mayer von Schopf (1930). Tophi appeared on the hands of a male 3-week-old infant born of healthy parents with no family history of gout. These grew with extraordinary rapidity and soon involved wrists, elbows, and ankles. The child died from bronchopneumonia. At necropsy, sodium urate tophi were found in almost all joints, as well as extensive deposits of urates in the kidneys, muscles, ligaments, and viscera. In particular, the kidneys were studded with numerous white tophaceous masses. Schopf emphasized that the causes of secondary gout had been excluded, and that the enormous amounts of uric acid contained in the tophi could only have arisen from endogenous purins, as there was no exogenous source. A similar example of malignant gout was described by Riley (1960) in a boy aged 3 years, who also suffered from cerebral palsy. He developed diffuse painful swellings of the fingers and toes, which increased rapidly in size, became lilac in colour, and showed white calcareous deposits. The skin was ulcerated and the blood uric acid was $10.6 \mathrm{mg} . / 100 \mathrm{ml}$. At 8 years, he was very emaciated, with typical gout of both hands and feet, and of the lobes of the ears. Radiographs of the hands were characteristic of severe gout.

Gout is less rare in the 'teens. Garrod (1876), in his masterly monograph, described gout in four children whose ages ranged from 7 to 16 years. Still (1927) reported a girl aged 12 who first developed gout at $3 \frac{1}{2}$ years and had had attacks of gout since then. There was a strong family history of gout and her father had also suffered from recurrent podagra since youth. Claiborne (1940) reported gout in a 14-year-old girl with recurrent swelling of the knee joints, usually provoked by minor injuries. The serum uric acid was $7.5 \mathrm{mg} . / 100 \mathrm{ml}$. and the pain was relieved promptly by colchicine. Berk (1948) described gross destructive tophaceous gout, with typical radiological changes, in a Filipino in Honolulu, whose symptoms started before the age of 11 years, an unusual feature being a normal blood uric acid level between 3 and $4 \mathrm{mg} . / 100 \mathrm{ml}$., though sodium urate crystals were obtained from the tophi. Bernstein (1948) reported two boys and two girls in whom the first attack of podagra occurred at the ages of $12,14,16$, and 16 respectively. All showed advanced crippling gouty arthritis and three, with extensive tophaceous deposits, developed severe deformities in later years. One had renal impair- 
ment and another suffered from calculi. A family history of gout could be obtained in only one case. A further instance of gout in a boy aged 15 is given by Flinchum and Powers (1951), and Ludwig, Bennett, and Bauer (1938) reported the case of a youth who developed generalized ankylosis of the joints simulating rheumatoid arthritis; the serum uric acid was $9 \cdot 2 \mathrm{mg}$. $/ 100 \mathrm{ml}$. and there was no history of gout in the family.

Primary gout has to be distinguished from that occurring secondary to disorders of the blood (Hickling, 1953). Typical gout with tophi and urate deposits in the kidney is recorded in a boy aged 5 years with gouty ancestors and aleukaemic lymphatic leukaemia (Vining and Thomson, 1934) and in another boy aged 11 years with leukaemia (Franck, 1944). Gout and anaemia-either hypochromic or haemolytic-in childhood is described by several authors (Lambie, 1940; Nordmann and Höhne, 1951; Morgano and Zino, 1953). Lambie (1940), in a comprehensive review of gout and blood dyscrasias in childhood, described a boy aged 14 with chronic erythronoclastic anaemia of obscure origin, hyperuricaemia, and multiple tophi; after splenectomy, the tophi gradually disappeared and the serum uric acid level fell to normal, with improvement of the anaemia. A high blood uric acid level was associated with chronic liver disease in two unusual cases, one of which developed gout (Jeune, Charrat, and Bertrand, 1957).

There are two types of primary gout in childhood. First, the adult disease. Although the average age at onset of gout is 40 years, 2 per cent. of patients date the start of their trouble to childhood (Bernstein, 1948). Tophi are then unusual, for they often do not develop until 15 or 20 years after symptoms have started, and renal complications are exceptional. Secondly, there is this fulminating or malignant gout. Its tempo is rapid and control most difficult; there is early crippling, renal damage, and premature death. Malignant gout is generally confined to childhood, though it may occur in adults (Spitz, Steinbrocker, Schwartz, and Schittone, 1949). A positive family history may or may not be present. The sex ratio is altered and females are more commonly affected than in adult cases, in which gout occurs in only 9 per cent. of women before the menopause (Turner, Frank, van Ausdal, and Bollet, 1960). The prognosis is bad; statistics are unavailable owing to the rarity of the condition and the lack of follow-up studies of those patients who have been reported in the medical press.

There are different metabolic causes for gout (Buchanan and Rollins, 1961: Seegmiller, Laster, and Howell, 1963). It is certain that the traditional provocative agents, such as a high purine diet, obesity, and alcoholic excess, play no part in the development of the disease in children. Isotopic studies in adults have shown an abnormal diversion of dietary glycine and other readily available metabolites to direct uric acid synthesis in some cases, so that the body produces uric acid not merely from purines but from these simple molecules (Seegmiller and others, 1963). There is evidence that this is the explanation of the childhood cases (Rosenthal, Gaballah, and Rafelson, 1964).

\section{Renal Disease}

Both brothers developed renal disease. Damage to the kidneys is common, seventeen of 55 cases in one series having chronic nephritis (Schnitker and Richter, 1936), and renal failure being the commonest cause of death (Talbott, 1943). The early lesion appears to be tubular damage and this is accompanied by an interstitial reaction, according to studies by renal biopsy (Greenbaum, Ross, and Steinberg, 1961). At necropsy, the kidneys are found to be shrunken, scarred, and laden with urate deposits in the medulla-these conforming to the shape, direction, and position of the collecting tubules. The inflammation and foreign-body reaction to the crystals has often destroyed the tubular structure and caused nephrosclerosis (Brown and Mallory, 1950).

Renal function in patients with gout though without nephropathy is normal (Schnitker and Richter, 1936). Many have considered that the kidneys of gouty subjects have an impaired capacity to excrete uric acid, but Yü, Berger, and Gutman (1962) found that gouty patients could excrete large extraneous loads as well as normal subjects and concluded that there was no intrinsic renal defect of urate excretion in gout. Renal damage is caused by an increase of uric acid in the blood and this would explain its early development in the two cases described. Duncan and Dixon (1960) showed, from a study of other pathological and experimental disorders with hyperuricaemia, that a high serum urate concentration is nephrotoxic. Mechanical factors may also play a part, for there is no doubt that massive excretion of uric acid, such as follows the irradiation of patients with leukaemia, can cause tubular obstruction and even fatal renal insufficiency (McCrea, 1955; Greenbaum and Stone, 1959).

\section{Spinal Disease}

Gout which involves the spine is recorded, though uncommonly (Collins, 1949). Lichtenstein and others (1956) found, during a detailed pathological study of eleven necropsies, that sections of the 
vertebral column might show conglomerate urate deposits within the intervertebral disk tissue, extending into the contiguous spongiosa of the bodies. Hall and Selin (1960) described a case with involvement of the posterior intervertebral joints, particularly where degenerative changes occurred, such as the neck and articulations between L4 and 5. There were extensive deposits of urates in the capsules and ligaments and over the articular cartilage. Our patient showed changes typical of gout in the sacroiliac joints, similar to those described by Talbott (1943). His brother had developed remarkable changes in the cervical vertebrae which contributed to his death. There was a thick band of urate deposits between the base of the skull and the atlas, forming an almost complete collar between the two bones. This had eroded the atlas, causing a pathological fracture in one place and forcing the anterior part of the atlas downward so that it lay opposite the disk between the axis and C3. This subluxation had caused a protrusion of the remains of the odontoid process upwards into the foramen magnum, even though the process was reduced to about half its normal size by tophaceous destruction (Kersley and others, 1950).

\section{Genetics of Gout}

The presence of a similar pattern of disease in the two brothers indicated a genetic origin. The mother had hyperuricaemia though she has never suffered from gout. No case of gout in the family was known. The genetics of gout and hyperuricaemia were studied by Smyth, Cotterman, and Freyberg (1948) who analysed 87 relatives of nineteen gouty families. Hyperuricaemia appeared to be due to a single autosomal dominant gene, though only a portion of the heterozygotes developed gouty arthritis. The genetic peculiarities of hyperuricaemia were also studied by Stecher, Hersh, and Solomon (1949) in 44 families with gout. They found that the incidence of hyperuricaemia in some families resembled the activity of an autosomal recessive gene, whereas in others it was more likely due to an autosomal dominant one; but this discrepancy could be explained only if the gene involved was autosomal dominant though lacking penetrance in both sexes, with a much lower penetrance in the female than in the male. A tentative estimate of the penetrance was about 84 per cent. in heterozygous males and about 12 per cent. or less in females. No female was affected below the age of 50 years.

\section{Visceral Lesions}

Tophaceous deposits in viscera are rare. Records exist of lesions of the heart, such as a tophus in the conducting tissues causing heart block (Hench and Darnall, 1933) or diffuse urate crystals seen microscopically in the interstitial connective tissues of the myocardium (Pund, Hawley, McGee, and Blount, 1960 ), or a tophus in the mitral valve (Bunim and McEwen, 1940; Pund and others, 1960). However, gouty deposits in the alimentary tract are unique. The reason for this immunity is no more understood than is the cause for the common sites of tophithe outer ear, hand, foot, elbow, and knee, in that order (de Sèze, Ryckewaert, Levernieux, and Marteau, 1958). These peripheral lesions may suggest that trauma or a circulatory effect encourages the precipitation of uric acid from the blood.

Tophi on the surface of the small bowel were visible with the naked eye (Fig. 6), and deposits of urate crystals were seen by the polarizing microscope in the intestinal wall. This had not been so in the patient's brother, the only abnormality in his bowel being early deposits of amyloid in the small blood vessels. The death of our patient from ileus was unexpected and unexplained. Although this coincided with investigation by jejunal biopsy and barium meal, there was no evidence from laparotomy or necropsy to indicate that either could be blamed. It was possible that omission of colchicine during this time caused death, perhaps from lack of its prolonged stimulating effect upon the bowel or from some metabolic reason; colchicine withdrawal had previously caused severe relapse of gout.

\section{Megaloblastic Anaemia}

Macrocytic anaemia had been diagnosed 10 years before death. No haematinic had been given, and later investigation showed that the anaemia was megaloblastic. The possibility of his gout being secondary to the megaloblastic anaemia can be dismissed. His brother had hypochromic anaemia, a low white cell count $\left(2,500 / \mathrm{mm}^{3}\right)$, without megaloblastosis; and his mother's serum uric acid was raised though her blood was normal. The frequency of megaloblastic anaemia in gout cannot be estimated from the literature, for, though anaemia is frequently noted, blood examinations are seldom complete. Other forms of anaemia, hypochromic or haemolytic, have been found in patients with gout and their cause is often not clear (Lambie, 1940; Talbott, 1959; Nordmann and Höhne, 1951).

Causes in the Alimentary Tract.-The cause of megaloblastic anaemia usually lies in the gastrointestinal tract. In this patient, Addisonian pernicious anaemia had been excluded by finding hydrochloric acid in the stomach during life and a normal gastric mucosa at necropsy. Furthermore, 
the anaemia was due to deficiency of folic acid, according to the results of the intravenous folic acid tolerance curve and the response to folic acid. Vitamin $\mathbf{B}_{12}$ was ineffective. Folic acid deficiency often arises from disorders of the small intestine, particularly from lesions of the jejunal mucosa, for it is probable that folic acid is absorbed in the jejunum (McIntyre, Sachs, Krevans, and Conley, 1956; Cox, Meynell, Cooke, and Gaddie, 1958).

The small intestine in our case was abnormal in two respects. The jejunal biopsy specimen showed changes in the villi, which could be classified as "partial villous atrophy" (Doniach and Shiner, 1957; Shiner, 1960). There was also tophaceous deposits throughout the wall of the entire small intestine. Multiple sections revealed a fairly widespread distribution of deposits of urates, though many were hardly visible to the naked eye. Interference with small intestinal function might theoretically have occurred because of an inflammatory foreign-body giant cell reaction to the deposits as in the renal lesion. The abnormalities in the villi might also have been due to this, as similar appearances occur in Crohn's disease where the primary lesion involves the submucosa (Shiner and Drury, 1962). Since the areas of tophaceous deposits bore no direct relation to the changes in the villi and must have affected only a relatively small proportion of the entire mucosa, this hypothesis is unlikely. The thickening of the mesentery with enlarged lymph nodes suggested the possibility of obstruction to the lymphatic drainage, but there was no histological evidence of dilated lacteals.

The chance that two disorders, gout and idiopathic steatorrhoea, were present cannot be excluded. Isolated cases of tophaceous gout and sprue have been reported (Morlock and Rosenberg, 1944; Lewis, 1962) but gout has been due to the megaloblastic anaemia, for this causes a raised serum uric acid (Zumoff, 1953) as in pernicious anaemia (Gettler and Lindeman, 1920; Riddle, 1929). Idiopathic steatorrhoea is unlikely in our patient since he did not show the physical characteristics of that condition (Cooke, Peeney, and Hawkins, 1953), and the jejunal biopsy specimen did not show the typical flat appearance. Furthermore, the characteristic radiological appearance of the small intestine was not present, and the faecal fat excretion was only at about the upper limit of normal.

\section{Possible Role of Colchicine}

The patient was an addict to colchicine and had been so for 12 years. Severe relapse occurred at once if he stopped taking it-proof indeed of the value of continuous colchicine therapy in prophy- laxis (de Sèze, Ryckewaert, Levernieux, Marteau, Dry, and Pannier, 1960; Yü and Gutman, 1961).

Symptoms of overdosage or poisoning due to colchicine arise mainly from the gastrointestinal tract (Wallace, 1961), and occur even after parenteral injection, for colchicine is excreted through the alimentary tract. Mild overdosage causes hyperperistalsis and diarrhoea. Poisoning results in dysphagia, abdominal pain, diarrhoea, and tenesmus with the passage of mucoid and bloody stools; necropsy then shows marked inflammation of the gastrointestinal tract. Therapeutic doses may cause hyperaemia of the stomach and intestine even after hypodermic injections (Sollmann, 1948) and haemorrhagic gastroenteritis has even been attributed to therapeutic doses of colchicine (Shanbrom and Rapoport, 1958). Many workers, after long experience with colchicine, state that they have never encountered pathological changes in the bowel due to colchicine; but the villi have not hitherto been studied by biopsy or examined carefully at necropsy.

Although damage to the villi could have been caused by direct irritation by the colchicine, a more likely possibility is its prolonged action on the cells in the crypts of Lieberkuhn. The surface epithelial cells of the villi are formed by dividing cells in the crypts of Lieberkuhn which ascend from the crypts like steps of a moving staircase (Fig. $5 b$ ). Their span of life is probably only 2 to 3 days before being cast off at the tip of the villus. Colchicine is an anti-mitotic agent and arrest of mitosis in these epithelial cells might prevent formation of the villus. With regard to possible effects of colchicine on the villi, the following observations of ourselves and others are of interest:

(a) Four patients with gout volunteered to take $0.5 \mathrm{mg}$. colchicine at hourly intervals until diarrhoea developed. A specimen of jejunal mucosa was obtained by a Crosby capsule but this was normal in each case. However, this experiment differed from our patient's case in that colchicine was only taken for 24 hours instead of for 10 years. Colchicine has also been given to patients dying from uraemia by Finger and Headington (1963), who found mitotic changes in epithelial cells of the villi.

(b) We investigated the effect of colchicine upon the intestinal mucosa of 45 rats and mice. Healthy male rats were given $0 \cdot 10 \mathrm{mg}$. colchicine per $100 \mathrm{~g}$. body weight in a single subcutaneous or intraperitoneal injection and mice were similarly injected with $0.5 \mathrm{mg}$. colchicine per $\mathrm{kg}$. body weight. The animals were killed 6 to 8 hours after receiving the colchicine. The stomach, duodenum, jejunum, and ileum were immersed in formalsaline immediately after opening the intestine. Sections were stained with haematoxylin and eosin, haematoxylin and van Gieson's stain, and occasionally with the periodic acid-Schiff technique. There was no alteration in the 
general outline of the shape of the villi or the mucosa seen under the dissecting microscope. Histological examination showed arrested mitotic figures in the epithelial cells of the crypts of Lieberkuhn with abnormal nuclear appearances, similar to those described by Brown and Seed (1945) in a fatal case of colchicine poisoning and by Leblond and Stevens (1948). Another group of rats was later given repeated equivalent doses of colchicine on several consecutive days by intragastric tube. After 4 days this produced striking changes in the villous structure-blunting and sometimes a flat surface somewhat reminiscent of that seen in patients with idiopathic steatorrhoea (Fig. 7). Similar results have been obtained by Williams (1963), who injected colchicine (0.54 $\mathrm{mg} . / 100 \mathrm{~g}$. body weight) into the gut of animals at laparotomy, the segment being clamped and completely filled with fluid for 2 minutes and then washed with saline, and by Clark and Harland (1963), who produced an experimental malabsorption syndrome in animals with jejunal atrophy by administering colchicine.

We probably failed to cause changes in the shape of the villi by parenteral injections of colchicine because they were not continued long enough. The colchicine that the patient was taking could not have caused a similar concentration of colchicine in the bowel to that obtained in these animal experiments; but the prolonged period of time over which he was taking it may have been the important factor, if indeed the changes in the villi were due to the colchicine itself.

\section{Other Possible Actions of Colchicine}

Colchicine, like any anti-mitotic agent, may directly affect the bone marrow, causing agranulocytosis and aplastic anaemia (Brown and Seed, 1945; Wallace, 1961). There was no evidence of depression of the bone marrow in this case; indeed it was hypercellular. Certain drugs, for example the anticonvulsants, may have a direct effect upon folic acid metabolism and cause megaloblastic anaemia (Hawkins and Meynell, 1958; Klipstein, 1964), and colchicine may be yet another drug of this kind. Finally, colchicine might cause acute folic acid deficiency, similar to the action of the metabolites used in cancer chemotherapy (Hiatt, Goldstein, and Tabor, 1958).

The results of this survey of the possible causes of megaloblastic anaemia in this patient are inconclusive. The study of other cases, if they occur, may provide the answer.

\section{Summary}

(1) A fatal case of malignant gout in a young man is described. Unusual features included the presence of tophi in the small intestine and a megaloblastic anaemia.

(2) The aetiology of the megaloblastic anaemia remains undecided. The possibilities that prolonged colchicine therapy or the tophaceous small intestine caused impaired small intestinal function are considered.

We are grateful to Dr. W. T. Smith for allowing us to study a group of rats which he was treating with colchicine for a different purpose.

\section{REFERENCES}

Berk, M. E. (1948). Amer. J. med. Sci., 215, 290.

Bernstein, S. S. (1948). J. Mt Sinai Hosp., 14, 747.

Brown, J., and Mallory, G. K. (1950). New Engl. J. Med., 243, 325.

Brown, W. O., and Seed, L. (1945). Amer. J. clin. Path., $15,189$.

Buchanan, D. L., and Rollins, J. M. (1961). Yale J. Biol. Med., 34, 31.

Bunim, J. J., and McEwen, C. (1940). Arch.Path., 29, 700.

Chanarin, L., Mollin, D. L., and Anderson, B. B. (1958). Brit. J. Haemat., 4, 435.

Claiborne, T. S. (1940). J. Amer. med. Ass., 115, 38.

Clark, P. A., and Harland, W. A. (1963). Brit. J. exp. Path., 44, 520.

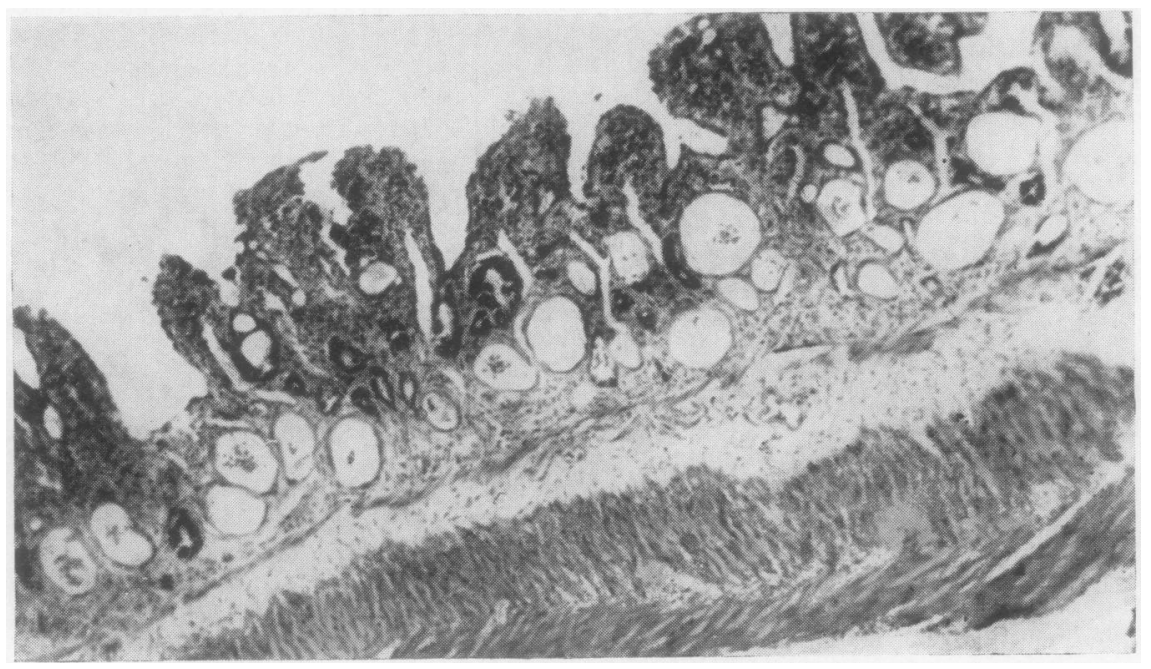

Fig. 7.- Jejunal mucosa of a rat which had been given rat which had been produced in the villi were similar to those found in our patient. 
Collins, D. H. (1949). In "The Pathology of Articular and Spinal Diseases". Arnold, London.

Cooke, W. T., Peeney, A. L. W., and Hawkins, C. F. (1953). Quart. J. Med., 22, 59.

Cox, E. V., Meynell, M. J., Cooke, W. T., and Gaddie, R. (1958). Gastroenterology, 35, 390.

Doniach, I., and Shiner, M. (1957). Ibid., 33, 71.

Duncan, H., and Dixon, A. St. J. (1960). Quart. J. Med., 29, 127.

Finger, J. E., and Headington, J. T. (1963). Amer. J. clin. Path., 40, 605.

Flinchum, D., and Powers, J. A. (1951). N.C. med. J., $12,433$.

Franck, G. (1944). Nord. Med., 21, 605.

Garrod, A. B. (1876). In "A Treatise on Gout and Rheumatic Gout", 3rd ed. Longmans, London.

Gettler, A. O., and Lindeman, E. (1920). Arch. intern. Med., 26, 453.

Greenbaum, D., Ross, J. H., and Steinberg, V. L. (1961). Brit. med. J., 1, 1502.

and Stone, H. F. H. (1959). Lancet, 1, 73.

Hall, M. C., and Selin, G. (1960). J. Bone Jt Surg., 42 A, 341.

Hawkins, C. F., and Meynell, M. J. (1958). Quart. J. Med., 27, 45.

Hench, P. S., and Darnall, C. M. (1933). Med. Clin. N. Amer., 16, 1371.

Hiatt, H. H., Goldstein, M., and Tabor, H. (1958). J. clin. Invest., 37, 829.

Hickling, R. A. (1953). Lancet. 1, 57.

Jeune, M., Charrat, A., and Bertrand, J. (1957). Arch. franc. Pédiat., 14, 897.

Kersley, G. D., Mandel, L., and Jeffrey, M. R. (1950). Ann. rheum. Dis., 9, 282.

Klipstein, F. A. (1964). Blood, 23, 68.

Lambie, C. G. (1940). Med. J. Aust., 1, 535.

Leblond, C. P., and Stevens, C. E. (1948). Anat. Rec., $100,357$.

Lewis, J. G. (1962). Ann. rheum. Dis., 21, 284.

Lichtenstein, L., Scott, H. W., and Levin, M. H. (1956). Amer. J. Path., 32, 871.

Ludwig, A. O., Bennett, G. A., and Bauer, W. (1938). Ann. intern. Med., 11, 1248.

McCrea, L. E. (1955). J. Urol. (Baltimore), 73, 29.

McIntyre, P. A., Sachs, M. V., Krevans, J. R., and Conley, C. L. (1956). Arch. intern. Med., 98, 541.

Mayer von Schopf, E. (1930). Klin. Wschr., 9, 2148.

Morgano, G., and Zino, F. (1953). Arch. E. Maragliano Pat. Clin., 8, 915.

Morlock, C. G., and Rosenberg, E. F. (1944). Ann. intern. Med., 20, 981.

Nordmann, M., and Höhne, K. H. (1951). Folia haemat. (Lpz.), 71, 98.

Pund, E. E., Hawley, R. L., McGee, H. J., and Blount, S. G. (1960). New Engl. J. Med., 263, 835.

Riddle, M. C. (1929). J. clin. Invest., 8, 69.

Riley, I. D. (1960). Arch. Dis. Childh., 35, 293.

Rosenthal, I. M., Gaballah, S., and Rafelson, M. E. (1964). Pediatrics, 33, 251.

Schnitker, M. A., and Richter, A. B. (1936). Amer. J. med. Sci., 192, 241.
Seegmiller, J. E., Laster, L., and Howell, R. R. (1963). New Engl. J. Med., 268, 764; 821.

Sèze, S. de, Ryckewaert, A., Levernieux, J., and Marteau, R. (1958). Ann. rheum. Dis., 17, 15.

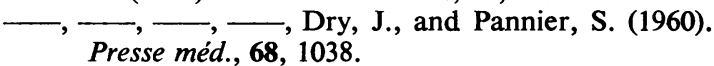

Shanbrom, E., and Rapoport, L. (1958). Ann. intern. Med., 48, 655 .

Shiner, N. (1960). Gut, 1, 48.

Shiner, M., and Drury, R. A. B. (1962). Amer. J. dig. Dis., N.S. 7, 744.

Smyth, C. J., Cotterman, C. W., and Freyberg, R. H. (1948). J. clin. Invest., 27, 749.

Sollmann, T. (1948). In "A Manual of Pharmacology and its Applications to Therapeutics and Toxicology", 7th ed. Saunders, Philadelphia.

Spitz, H., Steinbrocker, O., Schwartz, S., and Schittone, M. (1949). Amer. J. Med., 6, 513.

Stecher, R. M., Hersh, A. H., and Solomon, W. M. (1949). Ann. intern. Med., 31, 595.

Still, G. F. (1927). In "Common Disorders and Diseases of Childhood", 5th ed., p. 570. Oxford University Press, London.

Talbott, J. H. (1943). In "Gout”. Oxford University Press, London.

- (1959). Medicine (Baltimore), 38, 173.

Turner, R. E., Frank, M. J., Van Ausdal, D., and Bollet, A. J. (1960). Arch. intern. Med., 106, 400.

Vining, C. W., and Thomson, J. G. (1934). Arch. Dis. Childh., 9, 277.

Wallace, S. L. (1961). Amer. J. Med., 30, 439.

Williams, A. W. (1953). J. Path. Bact., 85, 467.

Yü, T. F., Berger, L., and Gutman, A. B. (1962). Amer. J. Med., 33, 829.

and Gutman, A. B. (1961). Ann. intern. Med., $55,179$.

Zumoff, B. (1953). Amer. J. med. Sci., 225, 674.

La goutte maligne avec l'intestin grêle tophacé et l'anémie mégaloblastique

\section{RÉSUMÉ}

1. On décrit un cas fatal de goutte maligne chez un homme jeune. La symptomatologie extraordinaire comprenait des tophi dans l'intestin grêle et une anémie mégaloblastique.

2. L'étiologie de l'anémie mégaloblastique est douteuse. Le traitement prolongé par la colchicine ou bien l'intestin grêle tophacé auraient pu affecter la fonction intestinale; on considère les deux possibilités.

La gota maligna con el intestino delgado tofáceo y la anemia megaloblástica

Sumario

1. Se describe un caso fatal de gota maligna en un hombre joven. Los síntomas extraordinarios incluyen tofos en el intestino delgado y una anemia megaloblástica.

2. La etiología de la anemia megaloblástica es dudosa. Se consideran las posibilidades de que el tratamiento prolongado con colchicina o el intestino delgado tofáceo hubieran podido dañar la función intestinal. 